\title{
Trophic ecology of syntopic anuran larvae, Rhinella arenarum (Anura: Bufonidae) and Hypsiboas cordobae (Anura: Hylidae): its relation to the structure of periphyton
}

\author{
Favio E. Pollo ${ }^{1,2}$, Luciana Cibils Martina ${ }^{2,3}$, Clarisa L. Bionda ${ }^{1,2 *}$, Nancy E. Salas ${ }^{1}$ and \\ Adolfo L. Martino ${ }^{1}$ \\ ${ }^{1}$ Ecología, Departamento de Ciencias Naturales, Facultad de Ciencias Exactas, Físico-Químicas y Naturales, UNRC, ruta 36 km \\ 601, Rio Cuarto, Córdoba, Argentina \\ 2 Consejo Nacional de Investigaciones Científicas y Técnicas (CONICET), Argentina \\ 3 Botánica Sistemática, Departamento de Ciencias Naturales, Facultad de Ciencias Exactas, Físico-Químicas y Naturales, UNRC, \\ Argentina
}

Received 12 February 2015; Accepted 18 May 2015

\begin{abstract}
The grazing of amphibian tadpoles has a significant effect on structure and function of freshwater algal communities. The aim of this study was to evaluate the composition of the diet, the amplitude and degree of overlap of the trophic niche of tadpoles of Rhinella arenarum and Hypsiboas cordobae. We captured tadpoles using nets in pond. Food items were identified to genus level and assigned to morphological guilds. The diet of both species consisted of microalgae, with a predominance of diatoms, but representatives of Cyanobacteria, Chlorophyta, Euglenozoa, Dinozoa and Ciliophora, were also recorded. A greater abundance was observed in $H$. cordobae diet, with diversity and richness showed significant differences between species. The proportion of individuals of each guild was different in the two species. As regards the size of the taxa consumed, both species consumed a higher proportion of small organisms. The differences in the diet of these species could be explained by different behaviors for food acquisition in the water column, as $H$. cordobae tends to be nektonic and $R$. arenarum benthic. The analysis of diets suggest that the quantity of food available to the tadpole anurans is very low; this could be due to water turbidity, depth, substrate type and strong variations in conductivity in a short period of time.
\end{abstract}

Key words: Syntopic anuran / larval diet / microalgae / trophic niche / morphological guilds

\section{Introduction}

The diet analysis is a tool to assess food availability in an environment, especially in those generalist habits species, and feeding strategies in syntopic species with similar behavior, however there are few studies comparing dietary overlap of amphibian larvae (Pavignano, 1990; Rossa Feres et al., 2004; Do Prado et al., 2009).

Amphibian larvae have a fundamental role in controlling ecosystem processes, in the regulation of primary producer's communities and as intermediaries in food webs of many environments (Connelly et al., 2008; Whiles et al., 2013). In addition, in some habitats, tadpoles could be a diverse and abundant component of many freshwater habitats, grazing of amphibian tadpoles has a significant

*Corresponding author: cbionda@exa.unrc.edu.ar, claribionda@yahoo.com.ar effect on structure and function of algal communities in an environment (Connelly et al., 2008). Therefore the information on feeding behaviors is critical to understand whether the anuran species adjust their diets to the habitats they occupy, according to the variation in the availability of different prey (Altig et al., 2007; Peltzer et al., 2010) which could affect the growth and development of these organisms (Falico et al., 2012).

Consequently, studies on amphibian larvae diet may represent a general measure of the offer and trophic availability of different habitats and be a tool for characterization and monitoring as bioindicator of environmental quality (Jüttner et al., 1996; Blanco et al., 2004; Díaz Quiros and Rivera Rondón, 2004; Bionda et al., 2012, 2013).

Several studies have been performed about the diet of larval amphibians in central Argentina (Arana et al., 2003, 2005; Bionda et al., 2012, 2013). But neither of these 
studies has focused on analyzing dietary overlap between species and the structure and architecture of the consumed algal community, thus becoming the first reference to Argentina, contributing significantly to the theoretical framework of the ecology of neotropical tadpoles.

The aim of this study was to evaluate the diet composition, amplitude and degree of trophic niche overlap of larval anurans of Rhinella arenarum Hensel, 1867 and Hypsiboas cordobae Barrio, 1965 and its relation to the structure of periphyton.

\section{Materials and methods}

\section{Study area}

The study area is located in center-south of the Sierra de Comechingones, Córdoba, Argentina (32 50'34"S$64^{\circ} 79^{\prime} 30^{\prime \prime} \mathrm{W}, 1200 \mathrm{~m}$ elevation.). Most part of the area is constituted by plutonic base, with high fluorine content, more than double the hosting metamorphic rock (Coniglio et al., 2010). This natural morphology in this area has contributed to the development of mines associate with the fluorite extraction, being the mine Cerros Negros; the only mine active at present since 1991 .

The region is characterized by a climate within the domain semi-humid to semi-dry trend in the plains and mountains, with water deficit in winter (Oggero and Arana, 2012). With respect to temperatures, the annual average is $17.2^{\circ} \mathrm{C}$; the maximum is $34.0^{\circ} \mathrm{C}$.

\section{Species of study}

R. arenarum presents a neotropical distribution (Frost, 2015), in a variety of habitats, including coastal environments, rural or urban areas (Lajmanovich et al., 2010); while, the distribution of $H$. cordobae is restricted to highlands of Córdoba and San Luis provinces, Argentina. This restricted distribution, to the highlands of central Argentina and with a broad altitudinal range, together with the report by the IUCN (2014) as species with insufficient data, makes this species interesting for study (Baraquet et al., 2013, 2015).

\section{Sampling}

In November 2013, using a hand net, six tadpoles of both species $R$. arenarum and $H$. cordobae between Gosner stages 30-39 (1960) were collected, from artificial ponds of approximately $15 \times 25 \mathrm{~m}$, vegetated with Typha sp. where sediments precipitate due to the flotation process that uses the mine. The captured larvae were anesthetized with a solution of chloroethylene and fixed in buffer formalin.

Water temperature, $\mathrm{pH}$, electrical conductivity, salinity and total dissolved solids were recorded with digital equipment TestTM 35-Series Multiparameter 35425-10.
In order to qualitatively determine the algal community present at the sampling site, three replicates of epiphyton (macrophytes) and epipelon (sediment) of the ponds were collected for identification under a 40x optical microscope.

\section{Analysis of the diet}

Under a stereoscopic microscope complete intestine of 12 larvas was removed and their contents were analyzed (only first third) according to Bionda et al. (2012). For species identification, a Zeiss optic microscope was used. For taxonomic analysis, specific bibliography for each particular group was used, and names were updated according to Spaulding et al. (2010), Komárek and Hauer (2013) and, Guiry and Guiry (2014). The counts were performed by direct methods at $400 \mathrm{x}$ magnification with slide and coverslip of $24 \times 50 \mathrm{~mm}$ following transects along the coverslip (Gómez et al., 2009, Rimet and Bouchez, 2011). The counting unit was the individual (cell, coenobium or colony) and for filamentous algae a $30 \mu \mathrm{m}$ length was counted as a single cell (Hill et al., 2000). Algal density estimation was based on Villafañe and Reid (1995).

The frequency of occurrence $(\mathrm{FO} \%$, percentage of individuals that consumed a given category of prey) and numerical frequencies $(\mathrm{N} \%)$ for each food item were calculated. Rank-abundance curves were constructed to analyze and show graphically the dominance of certain groups and the presence of rare taxa, and whether these relationships changed between species.

Total algal abundance was compared between species using the non-parametric Kruskal-Wallis test, because this variable did not meet the assumptions of analyses of variance (ANOVA). To describe the dietary diversity among different populations, diversity index $(\mathrm{H})$ according to Shannon and Weaver (1949) was calculated. Furthermore, we measured the evenness (E) for each population diet following Magurran (1987). These structural attributes were compared using one-way ANOVAs.

Rarefaction method was performed using Estimates version 8.2.0 (Colwell, 1997) to contrast the average diet diversity and richness in populations with different sample sizes. All algal taxa were grouped in three ecological guilds, low profile, high profile and motile species proposed by Passy (2007) and Passy and Larson (2011). The low profile guild comprises species of short stature, including prostrate, adnate, solitary centrics and slow moving species. Unicellular, colonial or filamentous algae extending higher on the substrate, comprising the high profile guild; and fast-moving biraphid diatoms or flagellated soft algae the motile guild. ANOVA were performed to compare the abundance and proportion of algae assigned to each morphological guild within species.

According to Rimet and Bouchez (2011), the taxa were assigned to five classes considering its biovolume (in $\mu \mathrm{m}^{3}$ ): $\mathrm{C}_{1}$ consists of taxa with less than $99 \mu \mathrm{m}^{3}, \mathrm{C}_{2}$ between 100 and $299 \mu \mathrm{m}^{3}, \mathrm{C}_{3}$ between 300 and $599 \mu \mathrm{m}^{3}, \mathrm{C}_{4}$ between 600 
Table 1. Percent (N\%) and occurrence frequencies $(\mathrm{FO} \%)$ of the more abundant algal genera $(\mathrm{FO}>50 \%)$ recorded in the gut contents of Rhinella arenarum and Hypsiboas cordobae tadpoles.

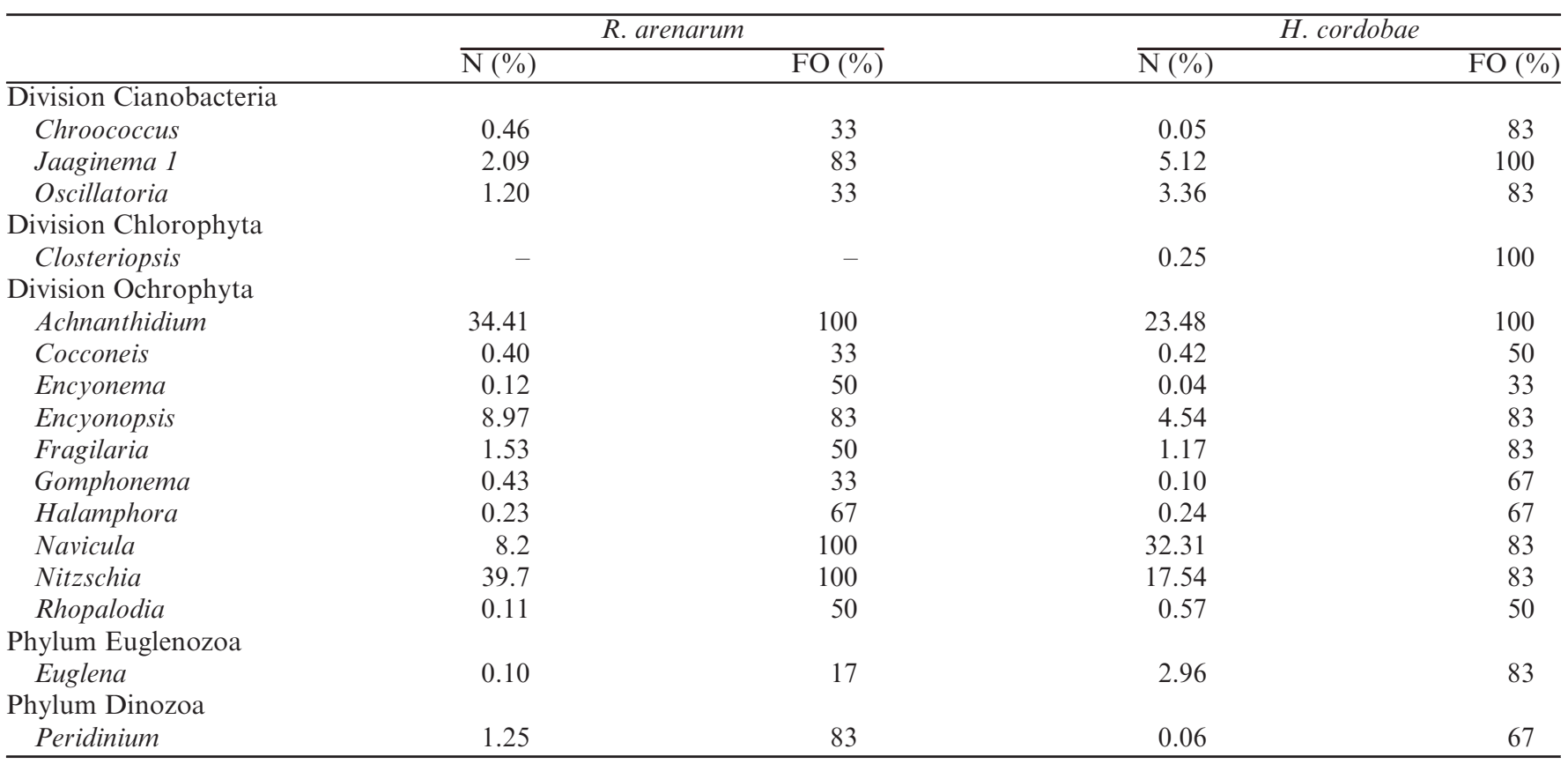

and $1499 \mu \mathrm{m}^{3}$ and $\mathrm{C}_{5}$ greater than $1500 \mu \mathrm{m}^{3}$. ANOVA were performed to compare the abundance and proportion of algae assigned to each size in the diet of each species. Analyses were performed using InfoStat (Di Rienzo et al., 2012).

We calculated dietary overlaps using Pianka's index (Pianka, 1973). Overlap values of 1.0 indicate identical diets or food volume, whereas overlap values of 0 indicate total dissimilarity in food items. Intermediate values are established as proposed by Peltzer et al. (2010) at the following levels: high $(>0.7)$, intermediate $(0.4-0.7)$ or low $(<0.4)$.

\section{Results}

The previous analysis of the availability of food revealed a low algal density with Nitzschia sp., Navicula sp., Achnanthidium sp. and Euglena sp., as the most frequent genera.

Six tadpoles for each species were analyzed. The diet of the two species consisted mainly of microalgae belonging to 44 genera (Table 1). There was a predominance of diatoms $(95$ and $83 \% R$. arenarum and $H$. cordobae, respectively) but representatives of Cyanobacteria, Chlorophyta, Euglenozoa, Dinozoa and Ciliophora were also recorded, the last one only in $H$. cordobae diet. In a smaller proportion, plant tissue, reproductive structures of fungi and rotifers were found in the diet.

The analysis of the diet of tadpoles of $R$. arenarum and $H$. cordobae revealed that the abundance of consumed algae was very different, with greater algal density in the gut of $H$. cordobae larvae (Fig. 1). In the diet of

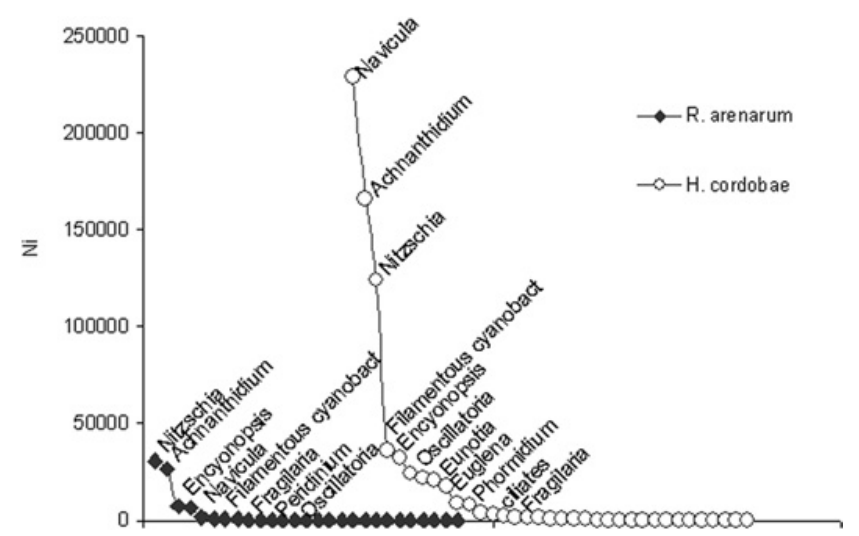

Fig. 1. Range-abundance curves of taxa recorded in the diet of Rhinella arenarum and Hypsiboas cordobae. The number of individuals is represented by $\mathrm{cm}^{2}$. Genera with abundances higher than $1 \%$ are indicated.

$R$. arenarum the abundance of the most common genera was less than 50.000 individuals $\mathrm{cm}^{2}$, while in larvae of $H$. cordobae the abundance of the most consumed genera was above the 100.000 individuals $\mathrm{cm}^{2}, 2 \mathrm{x}$ the consumed by the other species. It was also observed that the composition of the diet of each species was different, with different dominant species (Fig. 1). In the diet of $R$. arenarum the most abundant genera were Nitzschia sp. and Achnanthidium sp., representing almost $40 \%$ of the diet composition. However, in the diet of $H$. cordobae in addition to the genera mentioned for $R$. arenarum, Navicula sp., Euglena sp., filamentous cyanobacteria and ciliates became important. 

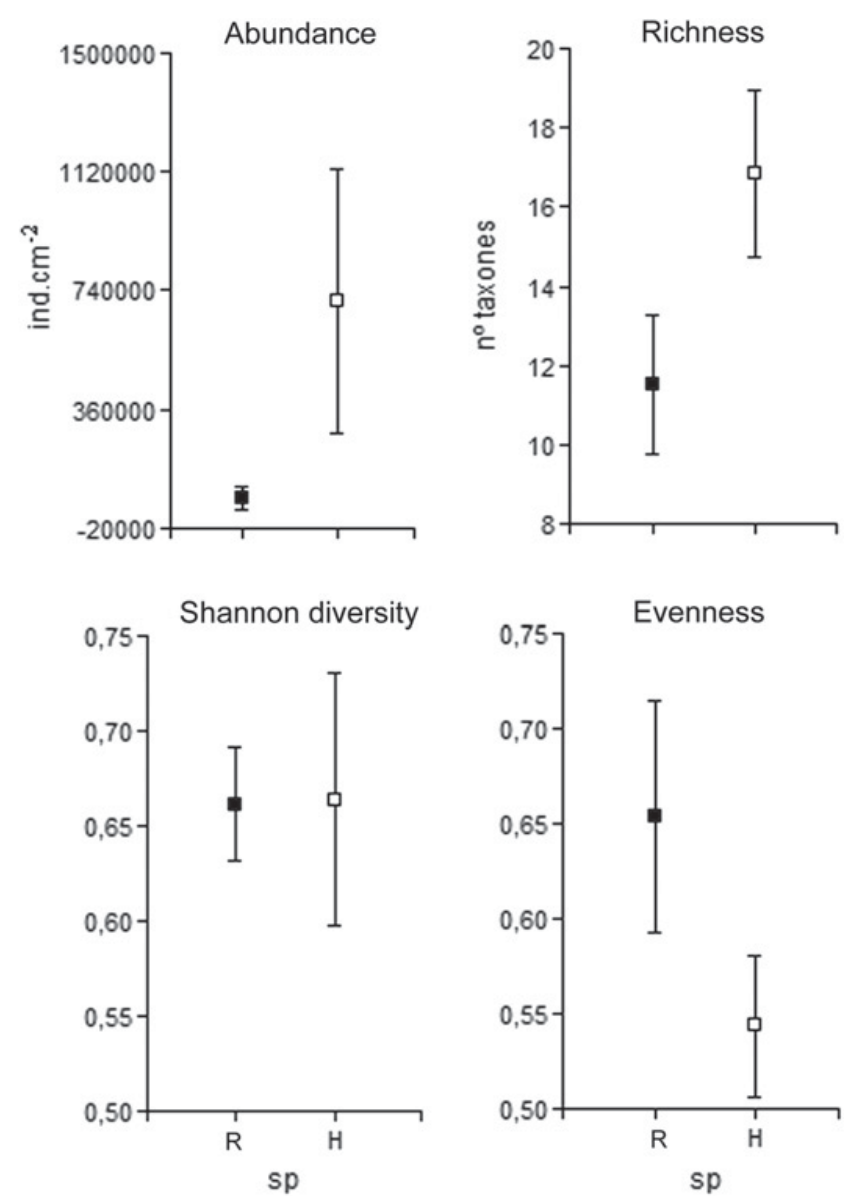

Fig. 2. Structural attributes of the algal community in the diet of Rhinella arenarum (black) and Hypsiboas cordobae (white) tadpoles. Means and standard errors are shown.

As to the structural attributes of the algal community consumed by the tadpoles a greater algal abundance was observed in the diet of $H$. cordobae (Kruskal-Wallis, $H=6.56 ; P<0.01$, Fig. 2). The diversity, evenness and richness in the diet showed no significant differences between species (diversity, $F_{1,10}=0.001 ; P=0.97$; evenness, $F_{1,10}=2.37 ; \quad P=0.15$ and richness $F_{1,10}=3.74$; $P=0.08$ ). However, the rarefaction technique revealed that the diversity and richness of consumed algae in the diet showed significant differences between species (diversity, $F_{2,9}=14.26 ; \quad P<0.001 ;$ richness $F_{2,9}=3.74$; $P<0.05$ ).

The proportion of individuals of each guild in the diet of the two species was different $\left(F_{2,15}=3.91 ; P<0.05\right.$ for $H$. cordobae and $F_{2,15}=25.12 ; P<0.0001$ for $R$. arenarum, Fig. 3(a)), with a higher proportion of motile organisms and low profile in H. cordobae and motile organisms in the diet of $R$. arenarum. However, the density of motile organisms in the diet of $H$. cordobae was higher, but may be due to the great variability of this variable no significant differences were found (Kruskal-Wallis, $H=8.84$; $P=0.19$, Fig. 3(b)).

The diet of $R$. arenarum showed greater abundance of taxa of size classes 1 and 3 (Kruskal-Wallis, $H=20.02$;

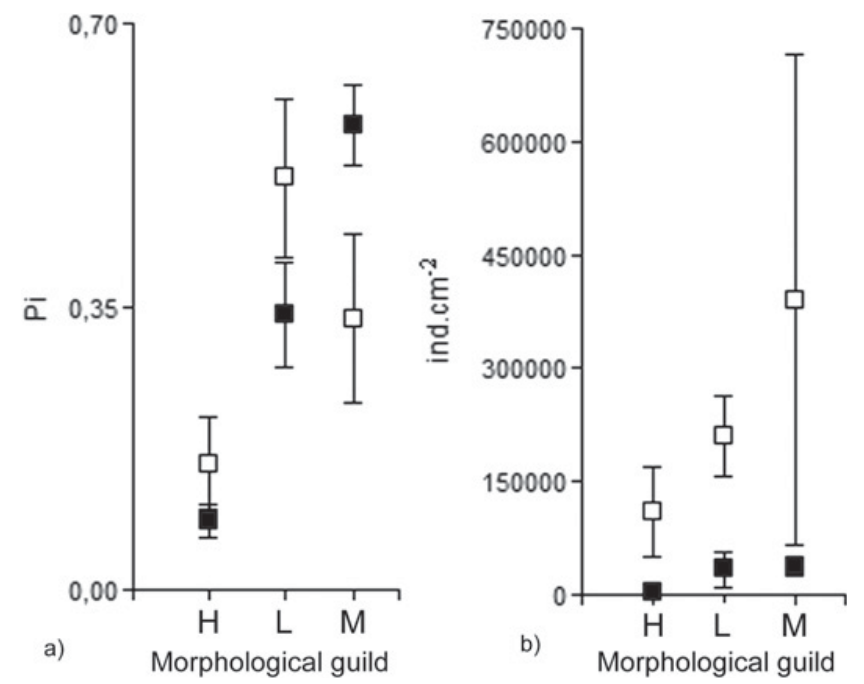

Fig. 3. Proportion (a) and density (b) of the organisms of morphological guilds: high profile $(\mathrm{H})$, low profile (L) and motile (M) in the diet of Rhinella arenarum (black) and Hypsiboas cordobae tadpoles (white).
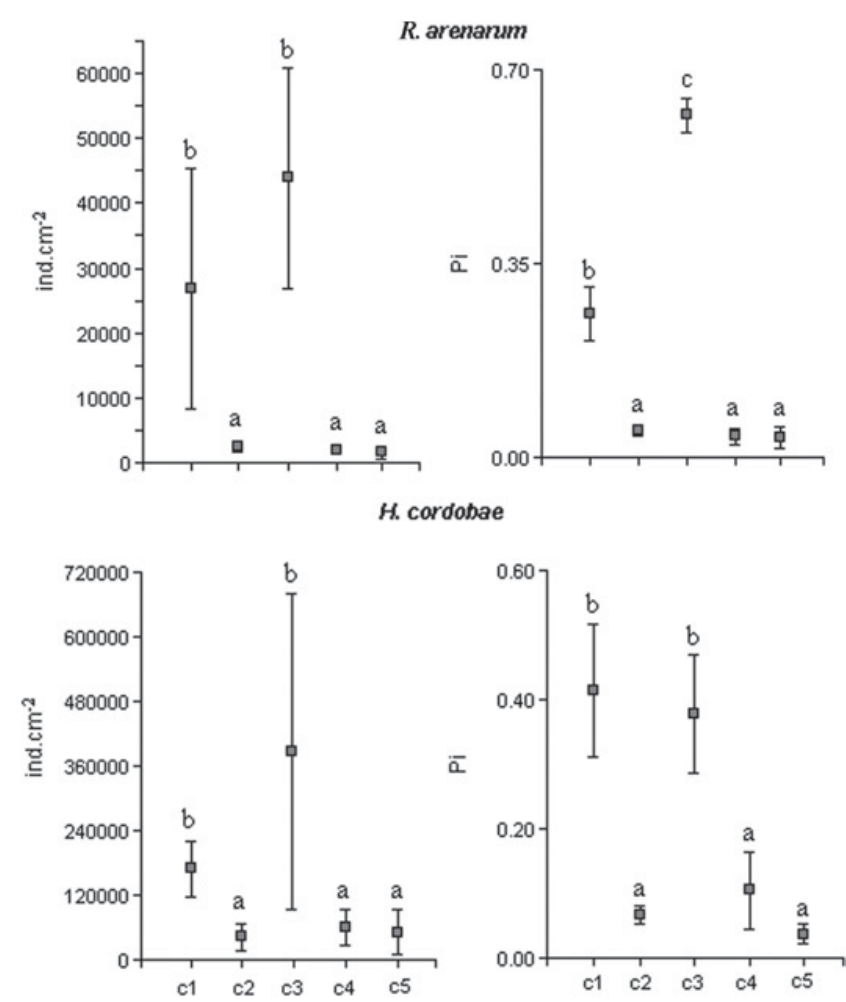

Fig. 4. Density and proportion of organisms for the different size classes $\left(\mathrm{C}_{1}-\mathrm{C}_{5}, \mathrm{C}_{1}\right.$ being the smallest $)$ in the diet of Rhinella arenarum and Hypsiboas cordobae tadpoles. Means and standard errors are shown. Letters show the results of post-hoc tests, mean values with the same letter are not significantly different.

$P<0.01$; Fig. 4); higher proportion of class $3(60 \%)$ followed by organisms of size $1(26 \%)\left(F_{4,25}=80.37\right.$; $P<0.001)$. Similar results were found for the diet of $H$. cordobae, with greater abundance and proportion of 
organisms of size classes 1 and 3 (Kruskal-Wallis for abundance, $H=8.91 ; \quad P<0.05$, and for proportions, $H=19.05 ; P<0.001)$, each of these size classes accounting for around $40 \%$ of the diet.

The general niches overlap was high $(G O=0.964)$ and the specific overlap indicated that $R$. arenarum overlapped intermediately to $H$. cordobae $(S O=0.612)$, while $H$. cordobae had a low overlap on the diet $R$. arenarum $(S O=0.187)$.

The mean values, standard deviation, minimum and maximum for the physico-chemical variables were: electrical conductivity $(\mu \mathrm{S})=1531.32 \pm 831.87 \quad(2.56-$ $1991)$; salinity $(\mathrm{ppm})=434.97 \pm 446.02$ (1.32-957); total dissolved solids $(\mathrm{ppm})=109.09 \pm 21.96 \quad(1.05-878)$; $\mathrm{pH}=8.64 \pm 0.24 \quad(8.13-8.94) ; \quad$ water temperature ${ }^{\circ} \mathrm{C}=22.72 \pm 4.18$ (16-26.5). This showed that the environment presented strong variations in the studied period, mainly due to the difference between maximum and minimum values of variables.

\section{Discussion}

The tadpoles of species, $R$. arenarum and $H$. cordobae, was found to coexist spatially but with variation in the use of trophic niche. The taxonomic composition of the diet of both species was different, and tadpoles of $H$. cordobae consumed a greater number of organisms. Furthermore, there were differences in the proportion of morphological guilds represented in the diet of each species. $R$. arenarum consumed greater proportion of motile algae, mainly represented by Nitzschia sp. Instead, in the diet of $H$. cordobae a higher proportion of motile algae were observed, represented by Nitzschia sp., Navicula sp., Euglena sp. and ciliates, and of low profile algae, mainly due to the abundance of Achnanthidium sp.

The trophic spectrum of tadpoles was in agreement with that of other species of benthic and nektonic tadpoles, mainly composed of animal remains, plant remains, diatoms and sediment (Lajmanovich and Fernández, 1995; Arana et al., 2003; Echeverría et al., 2007; Bionda et al., 2012, 2013). However, differences in resource use, type and size of prey consumed reported by the present paper suggested how species are structured to coexist in the same environment. In addition, this work represents one of the first contribution to the knowledge of the diet of syntopic amphibian larvae and its relationship to the architecture of periphyton.

The observed differences in the diet of these two species could be explained by differences in morphology (conformation of the buccal apparatus and buccopharyngeal cavity) and ecomorphological class assigned according to Altig and Johnston (1989) and McDiarmid and Altig (1999), where $R$. arenarum belongs to benthic group and $H$. cordobae to nektonic. $R$. arenarum larvae were observed grouped on plant debris floating in the water body, while larvae of $H$. cordobae swam through the water column. In this sense, Duellman and Trueb (1986) stated that partitioning of resources among anuran species may be due to differences in their position in the water column, a consequence of morphological adaptations for exploitation of specific microhabitats.

Moreover, Rossa Feres et al. (2004) argued that the anuran species differ in their ability to ingest particles of different sizes, which can be another cause of partitioning of resources. However they found that the particle size did not explain the selection of food. Similarly, in our study both species consumed larger proportion of small algae, with less than $600 \mu \mathrm{m}^{3}$ biovolume, because most consumed genera, and also the most abundant in the environment, corresponded to these size categories (Navicula, Nitzschia and Achnanthidium).

The general trophic niche overlap between diets was high, in agreement with other studies (Pavignano, 1990; Rossa Feres et al., 2004). A high overlap could be due to the competition between species by use of common resources and limited, or lack of competition or a nonselective foraging strategy, thus the most frequent items in the environment will be the most frequent items in the diet (Peltzer et al., 2010). Both scenarios are possible and additional data on resource availability and species interactions are needed for assessing trophic competence (Peltzer et al., 2010). As to specific overlap, our results showed that $R$. arenarum overlaid their diet intermediately with $H$. cordobae, while $H$. cordobae presented a low overlap on the diet of $R$. arenarum, suggesting that there is a partitioning of the food grade. Other authors have reported a high overlap in diets of larval amphibians; however Lajmanovich $(1997,2000)$ established that space and time can be much more important than resource partition in organizing tadpoles' communities. In this sense, both species could coexist as there is a significant temporal partition between their larval periods. The larvae of the genus Hypsiboas that inhabiting the mountains of central Argentina have a very long larval period, finding larval forms during the spring, summer, fall and even winter (Palermo, 1985). For its part $R$. arenarum larvae, possess a more limited larval period, between spring and early summer (Cei, 1980). These characteristics suggest a significant temporal partition; however, $H$. cordobae would have a greater overlap in the larval cycle of $R$. arenarum than vice versa. However, further studies could analyze the survival and development of these larvae, and ultimately assess the success in the larval recruitment, as well as the degree of overlap or competition between both species.

Availability of prey has proven to be one of the most important factors determining the diet of amphibians, but resources are complex to measure and generally not included in studies of diet of anurans (Peltzer et al., 2010). The semi-quantitative analysis of periphyton of the sampling site, that provided us an estimate of the availability of food in the ponds, revealed a low algal density, dominated by a few genera of algae. This is consistent with that recorded in the gut contents of the larvae and, as there were no preferences for some food items, confirms that their diets are good indicators of abundance and species composition of the 
environment (Lajmanovich and Fernández, 1995; Bionda et al., 2012).

Different studies demonstrate that grazing anurans larvae influences the periphyton, thereby acting as ecosystem engineers (Kupferberg, 1997; Mallory and Richardson, 2005; Connelly et al., 2008, 2014). This influence might be negative, as a result of the elimination of algae by direct grazing causing changes to the species composition of periphyton community, or positive, due to an increase in the surface area available for periphyton can colonize given the removal of detritus and adhered matter (Baffico and Úbeda, 2006; Holomuzki et al., 2010).

In both species intestinal contents presented a predominance of microalgae characteristics of anthropic environments, as some species from genera Navicula and Nitzschia, indicators of environmental conditions in various water bodies (Díaz Quiros and Rivera Rondón, 2004; Bionda et al., 2012), are resistant to high electrical conductivity and organic contamination (Ramírez and Plata Díaz, 2008; Yucra and Tapia, 2008). The predominance of the genus Euglena could indicate elevated content of organic matter in these ponds (Fabrizi, 2010). However, taxa reported by Arana et al. (2003) in the diet of $H$. cordobae of the high mountains of central Argentina are characteristic of environments slightly modified by human activity.

This study represents a first approach to the assessment of food ecology in syntopic species of amphibians and their relationship with the periphyton in the region, therefore constitutes a significant contribution to the theoretical framework in ecology of neotropical tadpoles. Further research is required about the food availability in natural and impacted environments. The importance of using the diet of larval amphibians as indicators of environmental quality and adaptation strategies of species to their environment is highlighted, as well as the overlap in diets as an indicator of the degree of competition or differentiation of trophic niches in syntopic species.

Acknowledgements. We thank the Argentinean National Research Council for Science and Technology (CONICET), SeCyT UNRC (PPI 18/C416) y FONCyT (PICT 2012-0932). The authors gratefully acknowledge the company Fluorite Córdoba SA allowing access to the area of Los Cerros Negros mine and the provided logistic support.

\section{References}

Altig R. and Johnston G.F., 1989. Guilds of anuran larvae: relationships among developmental modes, morphologies and habitats. Herpetol. Monogr., 3, 81-109.

Altig R., Whiles M.R. and Taylor C.L., 2007. What do tadpoles really eat? Assessing the trophic status of an understudied and imperiled group of consumers in freshwater habitats. Freshwater Biol., 52, 386-395.

Arana M., Salas N., Correa A. and di Tada I., 2003. Dieta de la larva de Hyla pulchella cordobae BARRIO, 1965 (Anura: Hylidae) en Pampa de Achala Córdoba Argentina. Bol. Asoc. Herpetol. Esp., 14, 1-2.
Arana M., Correa A., Salas N. and di Tada I., 2005. Dieta de larvas de Melanophryniscus stelzneri stelzneri (WEYENBERGH, 1874) (Anura, Bufonidae) de Atos Pampa, provincia de Córdoba, Argentina. Bol. Asoc. Herpetol. Esp., 15, 109-110.

Baffico G.D. and Úbeda C.A., 2006. Larval diet of the frog Alsodes gargola (Leptodactylidae: Telmatobiinae) and some ecological considerations on its role in alpine and mountain aquatic environments in Patagonia. Amphibia-Reptilia., 27, $161-168$.

Baraquet M., Salas N.E. and Martino A.L., 2013. Advertisement calls and interspecific variation in Hypsiboas cordobae and Hypsiboas pulchellus (Anura, Hylidae) from central Argentina. Acta Zool. Bulg., 65, 479-486.

Baraquet M., Grenat P.R., Salas N.E. and Martino A.L., 2015. Geographic variation in the advertisement call of Hypsiboas cordobae (Anura, Hylidae). Acta Ethol., 18, 79-86.

Bionda C., Gari N., Luque E., Salas N., Lajmanovich R., Martino A., 2012. Ecología trófica en larvas de Rhinella arenarum (Anura: Rhinellanidae) en agroecosistemas y sus posibles implicaciones para la conservación. Rev. Biol. Trop., 60, 771-779.

Bionda C., Luque E., Gari N., Salas N.E., Lajmanovich R.C. and Martino A.L., 2013. Diet of tadpoles of Physalaemus biligonigerus (Leiuperidae) from agricultural ponds in the central region of Argentina. Acta Herpetologica, 8, 141-146.

Blanco S., Ector L. and Becares E., 2004. Epiphytic Diatoms as water quality indicators in Spanish shallow lakes. Vie Milieu., 54, 71-79.

Cei J.M., 1980. Amphibians of Argentina, Monit, Zool. Ital. Monogr. 2, Nuova Serie, Firenze, Italy.

Colwell R.K., 1997. EstimateS: Statistical estimation of species richness and shared species from samples. Version 5.

Coniglio J., D'eramo F.J., Pinotti L.P., Demartis M., Agulleiro Insúa L.A. and Petrelli H.A., 2010. Control estructural de las mineralizaciones de fluorita del batolito Cerro Áspero, sierras pampeanas de Córdoba. Rev. Asoc. Geol. Argent., 67, 507-520.

Connelly S., Pringle C.M., Bixby R.J., Brenes R., Whiles M.R., Lips K.R., Kilham S. and Huryn A.D., 2008. Changes in stream primary producer communities resulting from largescale catastrophic amphibian declines: can small-scale experiments predict effects of tadpole loss? Ecosystems, 11, 12621276.

Connelly S., Pringle C.M., Barnum T., Hunte-Brown M., Kilham S., Whiles M.R., Lips K.R., Colón-Gaud C. and Brenes R., 2014. Initial versus longer-term effects of tadpole declines on algae in a Neotropical stream. Freshwater Biol., 59, 1113-1122.

Díaz Quiros C. and Rivera Rondón C.A., 2004. Diatomeas de pequeños ríos andinos y su utilización como indicadoras de condiciones ambientales. Caldasia, 26, 381-394.

Di Rienzo J.A., Casanoves F., Balzarini M.G., Gonzalez L., Tablada M. and Robledo C.W., 2012. InfoStat versión 2012, Grupo InfoStat, FCA, Universidad Nacional de Córdoba, Argentina.

Do Prado V.H.M., Fonseca M.G., de Almeida F.V.R., Neechi O. Jr. and Rossa-Feres D.C., 2009. Niche occupancy and the relative role of micro-habitat and diet in resource partitioning among pond dwelling tadpoles. S. Am. J. Herpetol., 4, 275-285.

Duellman W.E., Trueb L., 1986. Biology of Amphibians, Mc Graw-Hill Inc., USA. 
Echeverría D.D., Volpedo A.V. and Mascitti V.I., 2007. Diet of tadpoles from a pond in Iguazú National Park, Argentina. Gayana, 71, 8-14.

Fabrizi L., 2010. Eutrophication of water bodies introduction, Lenntech, Water treatment solutions, Accessed online 12 August 2014, http://www.lenntech.com/espanol/ Eutroficacion-de-las-aguas/introduccion.htm.

Falico D.A., López J.A., Antoniazzi C.E. and Beltzer A.H., 2012. Variación interpoblacional y ontogenética en la dieta de la rana llorona Physalaemus albonotatus (Anura: Leiuperidae). Rev. Mex. Biodivers., 83, 1187-1193.

Frost D.R., 2015. Amphibian species of the world, American Museum of Natural History, New York, Accessed online 23 February 2015, http://research.amnh.org/herpetology/ amphibia/.

Gómez N., Donato J.C., Giorgi A., Guasch H., Mateo P. and Sabater S., 2009. La biota de los ríos: los microorganismos autótrofos. In: Elosegi A. and Sabater S. (eds.), Conceptos y técnicas en ecología fluvial. Fundación BBVA, España, 219-242.

Gosner K., 1960. A simplified table for stading anuran embryos and larvae with notes on identification. Herpetologica, 16, 183-190.

Guiry M.D. and Guiry G.M., 2014. AlgaeBase, World-wide electronic publication, National University of Ireland, Galway, Accessed online 20 March 2014, http://www.algaebase.org.

Hill R.H., Herlihy A.T., Kaufmann P.R., Stevenson R.J., McCormick F.H. and Johnson C.R., 2000. Use of periphyton assemblage data as an index of biotic integrity. J. N. Am. Benthol. Soc., 19, 50-67.

Holomuzki J.R., Feminella J.W. and Power M.E., 2010. Biotic interactions in freshwater benthic habitats. J. N. Am. Benthol. Soc., 29, 220-244.

IUCN, 2014. Conservation International, and NatureServe. An analysis of amphibians on the 2008 IUCN red list, Accessed online 6 July 2014, http://www.iucnredlist.org/amphibians.

Jüttner I., Rothfritz H. and Ormerod S.J., 1996. Diatoms as indicators of river quality in the Nepalese Middle Hills with consideration of the effects of habitat specific sampling. Freshwater Biol., 36, 475-486.

Komárek J. and Hauer T., 2013. CyanoDR.cz - On-line database of cyanobacterial genera, Word-wide electronic publication, Univ. of South Bohemia \& Inst. of Botany AS CR, Accessed online 16 March 2014, http:// www.cyanodR.cz.

Kupferberg S., 1997. Facilitation of periphyton production by tadpole grazing: functional differences between species. Freshwater Biol., 37, 427-439.

Lajmanovich R.C., 1997. Alimentación de larvas de anuros en ambientes temporales del sistema del Río Paraná, Argentina. Doñana Acta Vertebrata, Sevilla., 24, 191-202.

Lajmanovich R.C., 2000. Interpretación ecológica de una comunidad larvaria de anfibios anuros. Interciencia., 25, 71-79.

Lajmanovich R.C. and Fernández V.C., 1995. Alimentación de larvas de Bufo arenarum Hensel, 1867 (Amphibia, Bufonidae) en ambientes del Río Paraná. Bol. Mus. Nac. Hist. Nat. Chile., 45, 7-18.

Lajmanovich R.C., Peltzer P., Junges C.M., Attademo A., Sanchez L.C. and Bassó A., 2010. Activity levels of B-esterases in the tadpoles of 11 species of frogs in the middle Paraná river flood plain: implication for ecological risk assessment of soybean crops. Ecotoxicol. Environ. Saf., 73, 1517-1524.

Magurran A., 1987. Ecological Diversity and its Measurements, EEUU: Vedrá, Princeton, Nueva Jersey.

Mallory M.A. and Richardson J.S., 2005. Complex interactions of light, nutrients and consumer density in a stream periphyton-grazer (tailed frog tadpoles) system. J. Anim. Ecol., 74, 1020-1028.

McDiarmid R.W. and Altig R., 1999. Tadpoles: the Biology of Anuran Larvae, University of Chicago Press, Chicago, EEUU.

Oggero A.J. and Arana M.D., 2012. Inventario de las plantas vasculares del sur de la zona serrana de Córdoba, Argentina. Hoehnea, 39, 171-199.

Palermo M.A., 1985. Anfibios y Reptiles fauna Argentina, Centro editor de América Latina S.A.

Passy S.I., 2007. Diatom ecological guilds display distinct and predictable behaviour a long nutrient and disturbance gradients in running waters. Aquat. Bot., 86, 171-178.

Passy S.I. and Larson C.A., 2011. Succession in stream biofilms is an environmentally driven gradient of stress tolerance. Microb. Ecol., 62, 414-424.

Pavignano I., 1990. Niche overlap in tadpole populations of Pelobates fuscus insubricus and Hyla arborea at a pond in north western Italy. Boll. Zool., 57, 83-87.

Peltzer P.M., Attademo A.M., Lajmanovich R.C., Junges C.M., Beltzer A.H. and Sanchez L.C., 2010. Trophic dynamics of three sympatric anuran species in a soybean agroecosystem from Santa Fé Province, Argentina. Herpetological J., 20, 261-269.

Pianka E.R., 1973. The structure of lizard communities. Annu. Rev. Ecol. Syst., 4, 53-74.

Ramírez C.A.M. and Plata Díaz Y., 2008. Diatomeas perifíticas en diferentes tramos de dos sistemas lóticos de alta montaña (páramo de Santurban, norte de Santander, Colombia) y su relación con las variables ambientales. Acta Biol. Colomb., 13, 199-216.

Rimet F. and Bouchez A., 2011. Use of diatom life-forms and ecological guilds to assess pesticide contamination in rivers: Lotic mesocosm approaches. Ecol. Indic., 11, 489-499.

Rossa Feres D.C., Jim J. and Gonçalves Fonseca M., 2004. Diets of tadpoles from a temporary pond in southeastern Brazil (Amphibia, Anura). Rev. Bras. Zool., 21, 745-754.

Shannon C. and Weaver W., 1949. The Mathematical Theory of Communications, EEUU, Universidad de Illinois, Urbana, Illinois.

Spaulding S.A., Lubinski D.J. and Potapova M., 2010. Diatoms of the United States, Accessed online 15 March 2014, http:// westerndiatoms.colorado.edu.

Villafañe V.E. and Reid F.M.H., 1995. Métodos de microscopía para la cuantificación del fitoplancton. In: Alveal K., Ferrario M.E., Oliveira E.C. and Sar E. (eds.), Manual de Métodos Ficológicos, Universidad de Concepción, Concepción, Chile, 169-185.

Whiles M.R., Hall R.O. Jr., Dodds W.K., Verburg P., Huryn A.D., Pringle C.M., Lips K.R., Kilham S.S., Colón Gaud C., Rugenski A. T., Peterson S. and Connelly S., 2013. Diseasedriven amphibian declines alter ecosystem processes in a tropical stream. Ecosystems, 16, 146-157.

Yucra H.A. and Tapia P.M., 2008. El uso de microalgas como bioindicadoras de polución orgánica en Brisas de Oquendo, Callao, Perú. Biologist (Lima), 6, 41-47. 